\title{
Front Matter: Volume 11741
}

, "Front Matter: Volume 11741," Proc. SPIE 11741, Infrared Technology and Applications XLVII, 1174101 (15 June 2021); doi: 10.1117/12.2598630

SPIE. Event: SPIE Defense + Commercial Sensing, 2021, Online Only 


\title{
PROCEEDINGS OF SPIE
}

\section{Infrared Technology and Applications XLVII}

\author{
Bjørn F. Andresen \\ Gabor F. Fulop \\ Lucy Zheng \\ Masafumi Kimata \\ John Lester Miller \\ Editors
}

\section{2-16 April 2021}

Online Only, United States

Sponsored and Published by

SPIE 
The papers in this volume were part of the technical conference cited on the cover and title page. Papers were selected and subject to review by the editors and conference program committee. Some conference presentations may not be available for publication. Additional papers and presentation recordings may be available online in the SPIE Digital Library at SPIEDigitalLibrary.org.

The papers reflect the work and thoughts of the authors and are published herein as submitted. The publisher is not responsible for the validity of the information or for any outcomes resulting from reliance thereon.

Please use the following format to cite material from these proceedings:

Author(s), "Title of Paper," in Infrared Technology and Applications XLVII, edited by Bjørn F. Andresen, Gabor F. Fulop, Lucy Zheng, Masafumi Kimata, John Lester Miller, Proc. of SPIE 11741, Seven-digit Article CID Number (DD/MM/YYYY); (DOI URL).

ISSN: 0277-786X

ISSN: 1996-756X (electronic)

ISBN: 9781510643192

ISBN: 9781510643208 (electronic)

Published by

SPIE

P.O. Box 10, Bellingham, Washington 98227-0010 USA

Telephone +1 3606763290 (Pacific Time)

SPIE.org

Copyright (C) 2021 Society of Photo-Optical Instrumentation Engineers (SPIE).

Copying of material in this book for internal or personal use, or for the internal or personal use of specific clients, beyond the fair use provisions granted by the U.S. Copyright Law is authorized by SPIE subject to payment of fees. To obtain permission to use and share articles in this volume, visit Copyright Clearance Center at copyright.com. Other copying for republication, resale, advertising or promotion, or any form of systematic or multiple reproduction of any material in this book is prohibited except with permission in writing from the publisher.

Printed in the United States of America by Curran Associates, Inc., under license from SPIE.

Publication of record for individual papers is online in the SPIE Digital Library.

\section{SP|E. DIGITAL}

Paper Numbering: A unique citation identifier (CID) number is assigned to each article in the Proceedings of SPIE at the time of publication. Utilization of CIDs allows articles to be fully citable as soon as they are published online, and connects the same identifier to all online and print versions of the publication. SPIE uses a seven-digit CID article numbering system structured as follows:

- The first five digits correspond to the SPIE volume number.

- The last two digits indicate publication order within the volume using a Base 36 numbering system employing both numerals and letters. These two-number sets start with 00, 01, 02, 03, 04, 05, 06, 07, 08, 09, 0A, OB ... 0Z, followed by 10-1Z, 20-2Z, etc. The CID Number appears on each page of the manuscript. 


\section{Contents}

NIR / SWIR

1174108 Performance of low noise InGaAs detector [11741-1]

$11741 \mathrm{OB} \quad$ Thick $\mathrm{Al}_{0.85} \mathrm{Ga}_{0.15} \mathrm{As}_{0.56} \mathrm{Sb}_{0.44}$ avalanche photodiodes on InP substrate [1 1741-4]

11741 OD Extended-short-wavelength infrared AllnAsSb and InPAsSb detectors on InAs [11741-6]

11741 OE Ultra low light CMOS image sensors [11741-7]

11741 OF Development of high-speed quantum dots/graphene infrared detectors for uncooled infrared imaging [11741-8]

\section{CRYOGENIC COOLING OF SENSING DEVICES}

$117410 \mathrm{~A} \quad$ Affordable cryocoolers for commercial IR imaging [11741-9]

$11741 \mathrm{OH} \quad$ High-availability cryocooling for infrared sensors [11741-10]

$1174101 \quad$ Radiation hard cryocooler electronics for HMWIR sensors [11741-11]

11741 OJ Applicable range and performance prediction model for Thales rotary coolers [11741-12]

\section{AI / MACHINE LEARNING ENABLING IMPROVED IR SYSTEM PERFORMANCE}

$11741 \mathrm{OL} \quad$ Polarimetric thermal-to-visible heterogeneous face recognition using coupled independent component analysis (Invited Paper) [11741-14]

$117410 \mathrm{M} \quad$ Visual-based defect detection for product classification: a machine learning approach (Invited Paper) [11741-15]

\section{T2SL AND HOT}

11741 ON Type II superlattice detectors at SCD (Invited Paper) [11741-16]

11741 OP Dual-band response in Type-Il superlattice infrared photodetectors with a modified pBp design [11741-18] 
11741 OR Self-aligned etching of subwavelength longwave infrared type-II superlattice pixels [11741-20]

11741 OS Small pixel MWIR sensors for low SWaP applications [11741-21]

$117410 \mathrm{OU} \quad$ High operating temperature T2SL digital focal plane arrays for earth remote sensing instruments (Invited Paper) [11741-23]

11741 OV Development status of T2SL infrared detector in JAXA (Invited Paper) [11741-24]

11741 OW HOT MWIR detector with $5 \mu \mathrm{m}$ pitch [11741-25]

11741 OX Type-II superlattices for SWaP and high-resolution detectors at IRnova [1 1741-26]

11741 OY HOT InAs/InAsSb nBn detector development for SWaP detector [1 1741-27]

1174110 Wafer-scale integration of antimonide-based MWIR FPAs (Invited Paper) [1 1741-29]

$1174111 \quad$ Volume MBE production trends for GaSb-based IR photodetector structures (Invited Paper) [11741-63]

\section{ELEVATED SKIN TEMPERATURE (EST) AND UNCOOLED FPAS}

$117411280 \times 32$ SOI diode-based uncooled IRFPAs for thermal detectors [11741-30]

1174113 Image signal processor for bolometers IR detectors [11741-31]

$1174114 \quad$ Accurate fever screening system with visible camera and thermograph [11741-32]

1174117 Testing and performance standards for elevated skin temperature (EST) screening systems using infrared cameras (Invited Paper) [11741-35]

\section{HGCDTE}

11741 1B Persistence and dark current characterization on HgCdTe short wave infrared imagers for astronomy at CEA and Lynred [1 1741-40]

11741 1C High operating temperature n-on-p extrinsic MWIR HgCdTe photodiodes [11741-41]

11741 ID Optical functions integrated onto a mid-wave infrared dectector [1 1741-42] 


\section{ALTERNATIVE FPA MATERIALS}

11741 1F QWIP as solution for mobile VLWIR imaging systems [11741-44]

$117411 G$ Development of small-format graphene infrared array sensors [11741-45]

$117411 \mathrm{H} \quad$ Graphene nanoribbon photogating for graphene-based infrared photodetectors [11741-46]

$1174111 \quad$ Enhanced photogating effect with turbostratic stacked graphene photodetectors for developing high-responsivity infrared sensors [11741-47]

\section{ADVANCED TECHNOLOGIES ENABLING HIGHER SYSTEM PERFORMANCE}

11741 1K High resolution gas mid-infrared spectroscopy using circular multi-reflection (CMR) cell [1 1741-49]

$117411 \mathrm{~L} \quad$ Image fusion systems for surveillance applications: design options and constraints for a triband camera [11741-50]

11741 1M A low SWAP-C 10-micron pitch 3-megapixel full motion video MWIR imaging system [11741-51]

\section{POSTER SESSION}

$117411 \mathrm{~N} \quad$ Flexible optoelectronic organic sensor for infrared detection [11741-52]

$1174110 \quad$ Metal-insulator-metal based plasmonic structures incorporating nanoslit for infrared rectification [11741-53]

11741 is Silicide-based photodetectors with localized surface plasmon resonance for mid-IR detection [11741-57]

$117411 \mathrm{~T} \quad$ Molecular-dynamics modeling of hydrogen-bond vibrational modes [11741-58]

$117411 \mathrm{U}$ Dark current improvement by an in-situ plasma treatment on type-II superlattice LWIR photodetectors [11741-59]

11741 IV Investigation of ICP dry etching of InAs/GaSb type-II superlattice LWIR photodetector [11741-60]

$117411 \mathrm{X} \quad$ Low noise AllnAsSb avalanche photodiodes on InP substrates for 1.55 um infrared applications [11741-62] 
Proc. of SPIE Vol. 11741 1174101-6

\section{Downloaded From: https://www.spiedigitallibrary.org/conference-proceedings-of-spie on 26 Apr 2023
Terms of Use: https://www.spiedigitallibrary.org/terms-of-use}

